Article

\title{
Effect of Three Polysaccharides (Inulin, and Mucilage from Chia and Flax Seeds) on the Survival of Probiotic Bacteria Encapsulated by Spray Drying
}

\author{
Mariela Bustamante ${ }^{1,2, *}$, Loreto Laurie-Martínez ${ }^{1}$, Daniela Vergara ${ }^{1,3}$, Rocio Campos-Vega ${ }^{4}$, \\ Mónica Rubilar ${ }^{1,5}$ and Carolina Shene ${ }^{1,2,5}$ \\ 1 Center of Food Biotechnology and Bioseparations, Scientific and Technological Bioresource Nucleus \\ BIOREN, Universidad de La Frontera, 01145 Avenue Francisco Salazar, Temuco 4780000, Chile; \\ 1.laurie01@ufromail.cl (L.L.-M.); d.vergara02@ufromial.cl (D.V.); monica.rubilar@ufrontera.cl (M.R.); \\ carolina.shene@ufrontera.cl (C.S.) \\ 2 Centre for Biotechnology and Bioengineering (CeBiB), Universidad de La Frontera, \\ 01145 Avenue Francisco Salazar, Temuco 4780000, Chile \\ 3 Doctoral Program in Sciences of Natural Resources, Universidad de La Frontera, \\ 01145 Avenue Francisco Salazar, Temuco 4780000, Chile \\ 4 Programa de Posgrado en Alimentos del Centro de la República (PROPAC), Research and Graduate Studies \\ in Food Science, School of Chemistry, Universidad Autónoma de Querétaro, \\ 76010 Santiago de Querétaro, Mexico; chio_cve@yahoo.com.mx \\ 5 Department of Chemical Engineering, Faculty of Engineering and Science, Universidad de La Frontera, \\ 01145 Avenue Francisco Salazar, Temuco 4780000, Chile \\ * Correspondence: mariela.bustamante@ufrontera.cl; Tel.: +56-45-2325491; Fax: +56-45-2732402
}

Received: 10 June 2020; Accepted: 25 June 2020; Published: 3 July 2020

\begin{abstract}
Chia seed mucilage (CM), flaxseed mucilage (FM), and inulin (INL) were used as encapsulating agents to evaluate the possibility of increasing the survival of Lactobacillus casei var. rhamnosus, renamed recently to Lacticaseibacillus rhamnosus, after spray drying. Moreover, the viability of encapsulated L. rhamnosus was determined during the 250 day storage period at $4{ }^{\circ} \mathrm{C}$. In a second stage, the conditions that maximized the survival of L. rhamnosus were evaluated on other probiotic bacteria (Lactiplantibacillus plantarum, Bifidobacterium infantis, and Bifidobacterium longum). Additionally, the viability of encapsulated probiotics during the 60 day storage period at 4 and $25{ }^{\circ} \mathrm{C}$ was evaluated. The conditions that maximize the survival of L. rhamnosus $(90 \%)$ predicted by a face-centered central composite design were $14.4 \% \mathrm{w} / \mathrm{v}$ of maltodextrin, $0.6 \% \mathrm{w} / \mathrm{v}$ of $\mathrm{CM}$, and $90^{\circ} \mathrm{C}$ of inlet air temperature. Additionally, under these encapsulating conditions, the survival of L. plantarum, B. infantis, and B. longum was $95 \%, 97 \%$, and $96 \%$, respectively. The probiotic viability improved during storage at $4{ }^{\circ} \mathrm{C}$ but decreased at $25^{\circ} \mathrm{C}$. The highest viability values obtained for probiotics during spray drying and during storage suggest a thermoprotector effect of $\mathrm{CM}$, which would ensure an optimal probiotic efficacy in the product, thus promoting its utilization in the food industry.
\end{abstract}

Keywords: microencapsulation; spray drying; probiotic bacteria; Lacticaseibacillus rhamnosus; flaxseed mucilage; chia seed mucilage; inulin

\section{Introduction}

The probiotics market was valued at USD 46.54 billion in 2017 [1] and is projected to grow to USD 76.85 billion by 2024 [2]. This growth is due to consumer awareness of the health benefits of probiotic-based products. Several studies have shown that probiotics not only enhance the health of the digestive system but also influence the care of the skin, oral cavity, female urogenital tract, 
and respiratory tract, among others [3,4]. Species in the Lactobacillus and Bifidobacterium genera are the most studied probiotic bacteria, and some of them are used by the food industry. Lactobacilli have a relevant role in controlling undesirable microbiota in the gut and are able to prevent the rise in pathogenic bacteria by producing antimicrobial metabolites [5], maintaining the stability of the gastrointestinal tract, preventing intestinal infections, and generally supporting intestinal health [6]. Lactobacillus casei var. rhamnosus (Lcr35), renamed recently to Lacticaseibacillus rhamnosus [7], has the ability to adhere to intestinal cells by exerting antibacterial activity [8], and has also be shown to be effective in treating children with bowel diseases such as chronic constipation [9]. Forestier et al. [10] showed that L. rhamnosus delayed respiratory tract colonization and infection by Pseudomonas aeruginosa when administrated orally. Kovachev and Dobrevski-Vacheva [11] determined that the application of vaginal ovules with L. rhamnosus (Lcr35) after conventional 5-notroimidazole treatment increased the clinical and microbiological efficacy of the therapy, and the microbial balance in the vaginal ecosystem was restored in women diagnosed with bacterial vaginosis. On the other hand, several studies have shown that a bacteriocin from Lactobacillus plantarum ATCC 8014, renamed recently to Lactiplantibacillus plantarum [7], exhibits inhibitory activity against Staphylococcus aureus, Escherichia coli, Listeria innocua, Pseudomonas aeruginosa, and biofilm forms of Serratia marcescens strains [12,13]. Furthermore, L. plantarum ATCC 8014 presents inhibitory activity against Clostridium spp. [14]. On the other hand, bifidobacteria are considered as one of the early colonizers in the newborn's gut, the presence of which is favored by the consumption of human breast milk, which presents several factors that promote the growth of these strains, such as lactulose and N-acetylglucosamine-containing saccharides and oligosaccharides [15]. Bifidobacteria have been incorporated into various food products because they show beneficial effects on human health ranging from protection against infection to different extraand intra-intestinal positive effects [16]. Yun et al. [17] determined that oral administration of B. longum ATCC 15707 improved the survival (70\%) rates of mice infected with Clostridium difficile, and the intestinal tissues maintained structural integrity with some degree of damage. Rodrigues et al. [18] demonstrated that $B$. longum ATCC 15707 supplementation increased the minerals content (calcium, phosphorus, and magnesium) in the tibia and gave it a higher fracture strength in rats. Sheng et al. [19] determined that the synbiotic treatment (Bifidobacterium infantis and xylooligosaccharide) was more effective than either the probiotic or prebiotic alone against dextran sulfate sodium-induced ulcerative colitis in rats. The efficacy of synbiotic treatment may be explained by the additive combination of the direct anti-inflammatory effects of the probiotic and prebiotic components and their ability to fortify colonic epithelial barrier integrity.

The therapeutic effect of probiotics is achieved when their consumption is at least $10^{6}-10^{7} \mathrm{CFU} / \mathrm{g}$ or $\mathrm{mL}$ [20], so the industry must ensure probiotic survival after the production process and viability during storage of the products containing them. Several studies have demonstrated that microencapsulation improves the survival and viability of probiotics [21-23]. Microencapsulation of probiotics is designed to increase their stability and viability during processing and storage of several types of products, and in the presence of gastric and intestinal fluids [24]. Spray drying is the most common method used to microencapsulate probiotics $[22,25]$ because it has a high production rate, low operation cost, and the product has low humidity, is stable, and occupies a small volume [26]. However, the main disadvantage of spray drying is the impact that the process temperature has on the cellular integrity of probiotics during drying: It reduces the stability of encapsulated bacteria during product storage due to osmotic stress, damage to the membrane, ribosome, DNA, and protein $[27,28]$.

The composition and concentration of the solids in the encapsulation solution are relevant factors because they define the degree of protection for probiotics against adverse environmental factors, such as thermal and dehydration damage during spray drying, storage conditions, and gastrointestinal conditions of the host. Maltodextrin, protein, polysaccharides, and reconstituted skimmed milk are the most frequently used encapsulating agents in the encapsulating solution to protect probiotics from the aforementioned adverse factors [25,26]. Some other materials have been suggested for use in the encapsulating solution, such as prebiotics, soluble fiber, microbial polysaccharides (pullulan), 
and fruit juices; the results are promising as they improve the survival and viability of probiotics during spray-drying encapsulation and during storage [22,25,29-33]. Prebiotics are of special interest because of their synbiotic relationship with probiotics and because some may act as a thermoprotector [34-36].

Inulin (INL) is a heterogeneous blend of fructose polymers that can be found in a wide range of plants, such as dahlia, garlic, Jerusalem artichoke, onions, chicory roots, and others [37]. INL is a functional food ingredient that can be used as a prebiotic, texture modifier, fat or sugar replacer, or dietary fiber [38]. The consumption of INL reduces the high triacylglycerol concentrations and, therefore, reduces the risk of atherosclerosis, decreases the risk of intestinal tract diseases (irritable bowel diseases and colon cancer), and enhances the absorption of calcium, magnesium, and iron [38].

Flaxseed (Linum usitatissimum L.) is considered a functional food because it contributes to nutrition and has shown numerous beneficial health effects [39]. This seed presents a high content of soluble fiber $(7-10 \%$ of seed weight), commonly known as flaxseed mucilage (FM) $[39,40]$. It is characterized as a mixture of two acidic (rhamnogalacturonan I) [41,42] and one neutral polysaccharide (arabinoxylan) [42,43]. FM has several potential applications, such as a texturing agent in the food industry and a lubricant for the skin surface in cosmetic applications. In addition, the syneresis of the gel decreases when FM is mixed with other hydrocolloids [44]. Furthermore, FM consumption can prevent intestinal inflammation, decrease glucose and cholesterol in the blood [45], alter the gut microbiota and improve insulin sensitivity in obese postmenopausal women [46], and suppress postprandial lipemia in young men [47].

Chia (Salvia hispanica L.) seeds are considered a safe and functional food, contributing to nutrition and preventing and treating several diseases such as cardiovascular diseases, inflammatory and nervous system disorders, and diabetes, among others [48]. In 2017, the European Parliament and the Council on novel foods declared chia seeds a novel food, and, therefore, able to be placed on the market [49]. Chia soluble dietary fiber is a clear mucilaginous gel known as chia seed mucilage (CM). It is composed of neutral sugars, D-xylose and D-glucose, showing the presence of various carbohydrates on its structure, forming a tetra-saccharide as proposed by Lin et al. [50]. The CM has a slimy, mucilaginous character at low concentrations, a property that will allow it to be widely used in the food, pharmaceutical, and cosmetic industries [51].

L. rhamnosus has been on the market for more than 20 years as a pharmaceutical product; however, studies evaluating the effect of spray-drying microencapsulation on its survival are limited. On the other hand, new encapsulating agents are constantly being sought, with better properties than those traditionally used. However, studies evaluating chia or flax seeds as a source of raw materials for encapsulating probiotics through spray drying are limited. Therefore, studies evaluating the survival and viability cell after drying and during storage are also limited. Although probiotic microencapsulation with INL is common, few studies have evaluated its effect on the survival of L. rhamnosus microencapsulated by spray drying.

The aims of this study were to evaluate the possibility of increasing survival of L. rhamnosus after spray drying using inulin or mucilage from chia or flax seeds as encapsulating agents. Moreover, the viability of encapsulated L. rhamnosus was determined during a 250 day storage period at $4{ }^{\circ} \mathrm{C}$. Then, in a second stage, the conditions that maximized the survival of L. rhamnosus were evaluated on other probiotic bacteria (L. plantarum, B. infantis, and B. longum). Additionally, we also evaluated the viability of encapsulated probiotic bacteria during the 60 day storage period at 4 and $25^{\circ} \mathrm{C}$.

\section{Materials and Methods}

\subsection{Materials}

Bifidobacterium infantis ATCC 15679, Bifidobacterium longum ATCC 15707, and Lactobacillus plantarum (Lactiplantibacillus plantarum) ATCC 8014 were from American Type Culture Collection (Rockville, MD, USA). Lactobacillus casei var. rhamnosus (Lacticaseibacillus rhamnosus) was from Lactil ${ }^{\circledR}$ (LaboratorioChile, 
Chile). Inulin was purchased from Terrium ${ }^{\circledR}$ (Chile). Flaxseed and chia seeds were acquired from the local market. L-cysteine- $\mathrm{HCl}$ was purchased from Calbiochem ${ }^{\circledR}$ (Darmstadt, Germany).

\subsection{Extraction of FM and $C M$}

The FM was extracted according to Bustamante et al. [52]. Briefly, seeds were extracted with hot distilled water at $90-95^{\circ} \mathrm{C}$ and $\mathrm{pH} 5.0$ for $30 \mathrm{~min}$ under agitation, at a 1:10 (w/v) ratio. The extraction was repeated three times.

The CM extraction was carried out according to Bustamante et al. [22] with some modifications. Seeds were extracted with hot distilled water at $80{ }^{\circ} \mathrm{C}$ and $\mathrm{pH} 5.0$ for $2 \mathrm{~h}$, at a $1: 40(\mathrm{w} / \mathrm{v})$ ratio. The extraction was repeated twice.

Then, both extracts, $\mathrm{CM}$ and FM, were spread on a tray and dried at $60^{\circ} \mathrm{C}$ in an air convection heat oven, milled and passed through a $0.425 \mathrm{~mm}$ mesh, and stored at $-20^{\circ} \mathrm{C}$ until use.

\subsection{Preparation of Probiotic Suspension}

Probiotics were pre-cultured twice with 5\% (v/v) inoculum in MRS (5 mL) broth and incubated at $37^{\circ} \mathrm{C}$ for $12 \mathrm{~h}$. For strains of the genus Bifidobacterium, MRS broth (Difco, USA) was supplemented with L-cysteine- $\mathrm{HCl}(0.05 \%, \mathrm{w} / \mathrm{v})$ and incubated under anaerobic conditions (GasPak ${ }^{\mathrm{TM}}$ anaerobiosis generator system, $\mathrm{BD}, \mathrm{USA}$ ). The probiotics for the encapsulation assays by spray drying were grown in MRS $(200 \mathrm{~mL})$ broth inoculated $(5 \%, \mathrm{v} / \mathrm{v})$ with the grown pre-culture and incubated at $37^{\circ} \mathrm{C}$ for $12 \pm 2 \mathrm{~h}$. Probiotics in the late-log phase were harvested by centrifugation $\left(6000 \times g\right.$ for $10 \mathrm{~min}$ at $\left.4{ }^{\circ} \mathrm{C}\right)$; the pellets were washed with sterile distilled water and, again, centrifuged as described above. Finally, the probiotics were re-suspended in sterile distilled water and added to the encapsulating solution. In this stage, the bacterial suspension presented a total viable count between $10^{9}$ and $10^{10} \mathrm{CFU} / \mathrm{mL}$.

\subsection{Effect of Inulin, or Mucilage from Chia or Flax Seeds, and Inlet Air Temperature on the Survival of L. rhamnosus after Spray Drying}

The effect of CM, FM, or INL as an encapsulating agent was determined on L. rhamnosus survival after spray drying. Bacterial suspensions fed to the spray dryer contained maltodextrin (MD, food grade, with a dextrose equivalent of 15 , Prinal $\left.{ }^{\circledR}\right)$ and different concentrations $(0,0.3,0.6 \% \mathrm{w} / \mathrm{v})$ of $\mathrm{CM},(0,0.1,0.2 \% \mathrm{w} / \mathrm{v}) \mathrm{FM}$, or INL $(0,5,10 \% \mathrm{w} / \mathrm{v})$ such that the total solids concentration was $15 \%$ $(\mathrm{w} / \mathrm{v})$. The effect of encapsulating agents on L. rhamnosus survival was determined at three inlet air temperatures $\left(90,110\right.$, and $\left.130^{\circ} \mathrm{C}\right)$. A response surface methodology (RSM) matrix was applied as the experimental design. The experiments were organized according to a face-centered central composite design with two variables (encapsulating agent and drying temperature) and three replicated center-point experiments. A total of 11 experiments were performed for each encapsulating agent (Table 1). The survival after spray drying and viability of L. rhamnosus during storage under the refrigerated condition $\left(4^{\circ} \mathrm{C}\right)$ was followed periodically for 40 days and then determined at 80 and 250 days.

Table 1. A design central composite face-centered with two variables, encapsulating agent (chia seed mucilage, flaxseed mucilage, and inulin) content (EAC) and drying inlet air temperature (T).

\begin{tabular}{|c|c|c|c|c|}
\hline \multirow{2}{*}{ Treatment } & \multicolumn{3}{|c|}{ Encapsulating Solution } & \multirow{2}{*}{$\mathrm{T}\left({ }^{\circ} \mathrm{C}\right)$} \\
\hline & \multicolumn{2}{|c|}{$\mathrm{EAC}^{+}(\%, \mathrm{w} / \mathrm{v})$} & $\mathrm{MD}^{+}(\%, \mathrm{w} / \mathrm{v})$ & \\
\hline 1 & INL & 0.0 & 15.0 & 90 \\
\hline 2 & & & & 110 \\
\hline 3 & & & & 130 \\
\hline 4 & & 5.0 & 10.0 & 90 \\
\hline 5 & & & & 110 \\
\hline
\end{tabular}


Table 1. Cont.

\begin{tabular}{|c|c|c|c|c|}
\hline \multirow{2}{*}{ Treatment } & \multicolumn{3}{|c|}{ Encapsulating Solution } & \multirow{2}{*}{$\mathrm{T}\left({ }^{\circ} \mathrm{C}\right)$} \\
\hline & \multicolumn{2}{|c|}{$\mathrm{EAC}^{+}(\%, w / v)$} & $\mathrm{MD}^{\dagger}(\%, \mathrm{w} / \mathrm{v})$ & \\
\hline 6 & & & & 130 \\
\hline 7 & & 10.0 & 5.0 & 90 \\
\hline 8 & & & & 110 \\
\hline 9 & & & & 130 \\
\hline 10 & $\mathrm{CM}$ & 0.0 & 15.0 & 90 \\
\hline 11 & & & & 110 \\
\hline 12 & & & & 130 \\
\hline 13 & & 0.3 & 14.7 & 90 \\
\hline 14 & & & & 110 \\
\hline 15 & & & & 130 \\
\hline 16 & & 0.6 & 14.4 & 90 \\
\hline 17 & & & & 110 \\
\hline 18 & & & & 130 \\
\hline 19 & FM & 0.0 & 15.0 & 90 \\
\hline 20 & & & & 110 \\
\hline 21 & & & & 130 \\
\hline 22 & & 0.1 & 14.9 & 90 \\
\hline 23 & & & & 110 \\
\hline 24 & & & & 130 \\
\hline 25 & & 0.2 & 14.8 & 90 \\
\hline 26 & & & & 110 \\
\hline 27 & & & & 130 \\
\hline
\end{tabular}

${ }^{+}$INL: Inulin, CM: Chia seed mucilage, FM: Flaxseed mucilage, MD: Maltodextrin.

2.5. Effect of Chia Seed Mucilage on the Survival After Spray Drying and Viability during Storage of L. plantarum and Strains of the Genus Bifidobacterium

This stage assessed the effect of the operation conditions $\left(0.6 \% \mathrm{w} / \mathrm{v}\right.$ of $\mathrm{CM}$ and $90{ }^{\circ} \mathrm{C}$ of inlet air temperature) that maximized the survival of L. rhamnosus during the spray-drying process on survival after spray drying and viability during storage of L. plantarum, B. infantis, and B. longum. Probiotics for the spray-drying assays were prepared according to item 2.3. The viability of encapsulated bacteria during storage was determined periodically for 60 days at 4 and $25^{\circ} \mathrm{C}$.

\subsection{Spray Drying}

The encapsulation process by spray drying was performed in a Lab-Plant SD-05 laboratory spray dryer, (Huddersfield, England), with a $1.5 \mathrm{~mm}$ diameter nozzle and main spray chamber of $500 \mathrm{~mm} \times 215 \mathrm{~mm}$. Probiotic suspensions were continuously mixed using a magnetic stirrer throughout the spray-drying process. The feed flow rate used was $6 \mathrm{~g} / \mathrm{min}$. The dry powder was collected in sterile glass bottles and stored under refrigeration $\left(4^{\circ} \mathrm{C}\right)$ until characterization.

\subsection{Analyses}

The CM and FM were characterized for proteins, lipids, fiber, ash, and non-nitrogen extract, according to official AOAC methods [53].

Probiotic count was determined by serial dilution in $0.1 \%(\mathrm{w} / \mathrm{v})$ sterile buffered peptone water, according to Bustamante et al. [22]. Probiotic viability was expressed as CFU/g of dry powder and the results were expressed as $\log \mathrm{CFU} / \mathrm{g}$. The percent survival of probiotics was calculated as proposed by Simpson et al. [54]:

$$
\text { Survival }(\%)=\left(\frac{\mathrm{N}}{\mathrm{N}_{0}}\right) \times 100
$$


where $\mathrm{N}$ and $\mathrm{N}_{0}$ represent $\log \mathrm{CFU} / \mathrm{g}$ of the spray-dried powder after drying and log CFU/g of dry matter in the suspension fed into the dryer, respectively.

The feed solutions $(10 \mathrm{~mL})$ viscosity comprising the sterile encapsulation solution and L. rhamnosus was determined using an AND Vibro SV-10 viscometer (A\&D Company, Limited, Japan) at $20^{\circ} \mathrm{C}$. The assay was performed in quadruplicate.

\subsection{Characterization of the Spray-Dried Product}

The morphology of the dried particles was evaluated with a scanning electron microscope (SEM) (SU3500, Hitachi, Japan) according to Bustamante et al. [22]. In the analysis, a small amount of dry particles was deposited and dispersed onto the sample holder equipped with double-sided carbon tape. The particles size was determined with SEM.

The residual moisture content of the spray-dried powders was determined according to the methodology established by the International Dairy Federation [55], i.e., the sample was oven-drying at $102{ }^{\circ} \mathrm{C}$ until reaching constant weight.

\subsection{Statistical Analysis}

The Design Expert 6.0 statistics software (Stat-Ease, Minneapolis, Mn, USA) was used to perform statistical analysis. Analysis of variance (ANOVA) was applied to determine the significance $(p<0.05)$ of the encapsulating agent concentration and drying inlet air temperature on the survival of L. rhamnosus. Significant differences between mean values were detected using Tukey's test $(p<0.05)\left(\right.$ Minitab $^{\circledR}$ version 17.1.0).

\section{Results and Discussion}

\subsection{Effect of Inulin, or Mucilage from Chia or Flax Seeds, and Inlet Air Temperature on the Survival of} L. rhamnosus after Spray Drying

Prior to the encapsulation assay, CM and FM were characterized. The results showed that the main component of CM was the non-nitrogen extract (64.15\%), followed by proteins (14.43\%), lipids $(1.07 \%)$, fiber $(2.35 \%)$, and ash $(12.18 \%)$, while the main component in FM was non-nitrogen extract $(67.21 \%)$, followed by proteins $(15.74 \%)$, lipids $(0.55 \%)$, fiber $(2.04 \%)$, and ash $(9.11 \%)$.

The effect of CM $(0,0.3,0.6 \% \mathrm{w} / \mathrm{v}), \mathrm{FM}(0,0.1,0.2 \% \mathrm{w} / \mathrm{v})$, and INL $(0,5,10 \% \mathrm{w} / \mathrm{v})$ as a component of the encapsulating solution on the survival of $L$. rhamnosus after spray drying was tested at different inlet air temperatures $\left(90,110\right.$, and $\left.130^{\circ} \mathrm{C}\right)$. The RSM with a face-centered central composite design was used to determine the influence of the encapsulating agent and inlet air temperature on the survival of L. rhamnosus after spray drying; in Table 2, the results obtained in the nine drying runs for each encapsulating agent are shown.

The viscosity is a relevant property for spray drying; when the solids content increases in the encapsulating solution, its viscosity increases, resulting in large droplet sizes, which demands higher inlet air temperatures, reducing the viability of probiotics. In this context, we carry out preliminary tests to determine the concentration of the encapsulating agent (CM and FM), allowing small drops to be produced during spraying. The results showed that the concentrations that make the difference in the production of small drops or larger ones were $0.6 \%(\mathrm{w} / \mathrm{v})$ and $0.2 \%(\mathrm{w} / \mathrm{v})$ for CM and FM, respectively. The INL $(10 \%, \mathrm{w} / \mathrm{v})$ concentration was selected to maintain the total solids content at $15 \%$ $(w / v)$ in the encapsulation solution and the minimum concentration suggested by Corcoran et al. [26].

The viscosity of the encapsulating solution increases when the concentration of the encapsulating agent is increased, such as in CM (3.21 and $37.78 \mathrm{mPa}$ s for 0 and $0.6 \% \mathrm{w} / \mathrm{v}$, respectively) and FM (2.36 and $6.22 \mathrm{mPa}$ s for 0 and $0.2 \% \mathrm{w} / \mathrm{v}$, respectively) (Table 2). The viscosity of the encapsulating solution with CM was significantly $(p<0.05)$ higher compared to FM and INL. CM has a slimy mucilaginous character at low concentrations due to it being constituted mainly by carbohydrates such as D-xylose and $\alpha$-D-glucose, and 4-0-methyl- $\alpha$-D-glucuronic acid at a ratio of 2:1:1, respectively [50,51]. 
Another study reported that the high viscosity of $\mathrm{CM}$ solution can be attributed to inter-molecular chain entanglement in the aqueous medium due to the presence of 4-O-methyl glucuronic acid substituent [56]. Moreover, the increase in viscosity attributed to the increase in the CM and FM concentration in the dispersion could be due to hydrodynamic forces and the formation of an interfacial film that produces an increased restriction of intermolecular motion [57].

The highest concentration of each encapsulating agent exhibited high probiotic survival when the lowest drying inlet air temperature $\left(90^{\circ} \mathrm{C}\right)$ was evaluated, $81 \%(\mathrm{INL}, 10 \% \mathrm{w} / \mathrm{v}), 90 \%(\mathrm{CM}, 0.6 \%$ $\mathrm{w} / \mathrm{v}$ ), and $83 \%(\mathrm{FM}, 0.2 \% \mathrm{w} / \mathrm{v}$ ) (treatment 7,16 , and 25, Table 2, respectively). Moreover, for each type and concentration of encapsulating agent, the survival of L. rhamnosus significantly decreased as the drying inlet air temperature was increased from 90 to $130^{\circ} \mathrm{C}$. This fact can be explained by the loss of viability of L. rhamnosus during convective thermal processing related to cellular lesions resulting from the combined effects of heat and mechanical stress [58]. In previous studies, we evaluated the effect of $\mathrm{CM}(0.2,0.4$ and $0.6 \%, \mathrm{w} / \mathrm{v})$ as a component of the encapsulating solution on L. acidophilus La-05 survival. The results showed a survival of $75.7 \%$ when L. acidophillus La-05 was encapsulated with $0.6 \% \mathrm{CM}$ and dried at $110{ }^{\circ} \mathrm{C}$ [22], a similar survival trend to that obtained in the present study. However, the rate survival of probiotic bacteria depends on the strain [54].

Table 2. Viscosity of encapsulating solution ( $\mu$ ), moisture content of powder, and survival of L. rhamnosus after spray drying, and response given by the model derived from the experimental data.

\begin{tabular}{|c|c|c|c|c|c|}
\hline Treatment & $\mu^{\dagger}(\mathrm{mPa} s)$ & Moisture ${ }^{\dagger}(\%)$ & $\begin{array}{c}\text { Predicted } \\
\text { survival (\%) }\end{array}$ & $\begin{array}{l}\text { Experimental } \\
\text { Survival }^{++}(\%)\end{array}$ & $\begin{array}{l}\text { Student } \\
\text { Residual }\end{array}$ \\
\hline 1 & $3.21 \pm 0.02 \mathrm{de}$ & $5.68 \pm 0.27^{b c}$ & 80.89 & $79.54 \pm 0.25$ & -1.18 \\
\hline 2 & & $4.01 \pm 0.24 \mathrm{ef}^{\mathrm{ef}}$ & 67.48 & $68.72 \pm 1.20$ & 0.71 \\
\hline 3 & & $3.48 \pm 0.16 \mathrm{gl}$ & 61.46 & $61.57 \pm 0.74$ & 0.09 \\
\hline 4 & $2.14 \pm 0.09^{e}$ & $6.53 \pm 0.28^{a}$ & 75.24 & $78.47 \pm 0.74$ & 1.83 \\
\hline 5 & & $3.96 \pm 0.24 e^{e f}$ & 59.33 & $58.14 \pm 1.52$ & -1.08 \\
\hline 6 & & $3.98 \pm 0.19$ ef & 50.81 & $51.14 \pm 2.18$ & 0.18 \\
\hline 7 & $2.06 \pm 0.07^{\mathrm{e}}$ & $5.14 \pm 0.16^{\mathrm{cd}}$ & 83.02 & $81.14 \pm 0.63$ & -1.64 \\
\hline 8 & & $3.66 \pm 0.20$ ef & 64.60 & $66.91 \pm 2.09$ & 1.31 \\
\hline 9 & & $3.61 \pm 0.14^{\mathrm{ef}}$ & 53.58 & $53.16 \pm 0.29$ & -0.37 \\
\hline 10 & $3.21 \pm 0.11^{\mathrm{de}}$ & $5.68 \pm 0.27^{b c}$ & 81.79 & $83.45 \pm 3.56$ & 0.92 \\
\hline 11 & & $4.01 \pm 0.24$ ef & 70.16 & $68.72 \pm 1.20$ & -0.71 \\
\hline 12 & & $3.48 \pm 0.16 \mathrm{gl}$ & 58.53 & $61.57 \pm 0.74$ & 1.69 \\
\hline 13 & $18.30 \pm 0.79^{b}$ & $4.04 \pm 0.18^{j}$ & 84.43 & $83.04 \pm 0.59$ & -0.68 \\
\hline 14 & & $4.01 \pm 0.31$ ef & 72.80 & $71.67 \pm 1.98$ & 0.43 \\
\hline 15 & & $2.99 \pm 0.15 \mathrm{~g}$ & 61.18 & $59.44 \pm 1.84$ & -0.85 \\
\hline 16 & $37.78 \pm 1.54^{\mathrm{a}}$ & $4.72 \pm 0.21^{\mathrm{d}}$ & 87.07 & $89.98 \pm 0.90$ & 1.62 \\
\hline 17 & & $3.73 \pm 0.17$ ef & 75.44 & $73.91 \pm 0.73$ & -0.75 \\
\hline 18 & & $3.71 \pm 0.17^{\text {ef }}$ & 63.82 & $65.70 \pm 0.63$ & 1.05 \\
\hline 19 & $3.21 \pm 0.01 \mathrm{de}$ & $6.23 \pm 0.26^{\mathrm{ab}}$ & 80.73 & $79.54 \pm 0.25$ & -0.41 \\
\hline 20 & & $4.01 \pm 0.24 \mathrm{ef}^{\mathrm{f}}$ & 70.37 & $68.72 \pm 1.20$ & -0.49 \\
\hline 21 & & $3.48 \pm 0.16 \mathrm{gl}$ & 60.00 & $61.57 \pm 0.74$ & 0.54 \\
\hline 22 & $4.79 \pm 0.10^{c d}$ & $6.20 \pm 0.31^{\mathrm{ab}}$ & 83.46 & $80.81 \pm 0.07$ & -0.79 \\
\hline 23 & & $5.14 \pm 0.12^{\mathrm{cd}}$ & 73.09 & $76.34 \pm 2.07$ & 0.84 \\
\hline 24 & & $3.54 \pm 0.17^{e f}$ & 62.72 & $58.14 \pm 0.29$ & -1.37 \\
\hline 25 & $6.22 \pm 0.27^{c}$ & $5.61 \pm 0.24^{\mathrm{c}}$ & 86.18 & $83.46 \pm 0.15$ & -0.93 \\
\hline 26 & & $2.20 \pm 0.12^{h}$ & 75.81 & $80.83 \pm 0.11$ & 1.50 \\
\hline 27 & & $2.38 \pm 0.09 \mathrm{~h}$ & 65.45 & $61.89 \pm 1.13$ & -1.21 \\
\hline
\end{tabular}

${ }^{+}$Mean values of four experiments; ${ }^{+\dagger}$ Mean values of two replicates, except in the central point where there were three replicates. Different letters in the same column indicate significant differences by Tukey's one-way analysis of variance $(p<0.05)$. 
The survival of L. rhamnosus in terms of CM and FM concentration, and inlet air temperature (T) fits a linear relationship according to the following equations:

$$
\begin{array}{ll}
\mathrm{S}(\%)=72.80+2.64 \mathrm{CM}-11.63 \mathrm{~T} & \mathrm{r}^{2}=0.94 \\
\mathrm{~S}(\%)=73.09+2.72 \mathrm{FM}-10.30 \mathrm{~T} & \mathrm{r}^{2}=0.85
\end{array}
$$

Meanwhile, the survival in terms of INL and T fits a quadratic equation:

$$
\mathrm{S}(\%)=59.33-1.44 \mathrm{INL}-12.21 \mathrm{~T}+6.71 \mathrm{INL}^{2}+3.70 \mathrm{~T}^{2}-2.50 \mathrm{INL} \times \mathrm{T} \quad \mathrm{r}^{2}=0.97
$$

The three models have predictive capability deduced from the signal-to-noise ratio (higher than 4), the small residual value, and Student residual and the "Lack of Fit F-value" (not significant) are appropriate for the description of the response surface. Only inlet air temperature significantly contributed $(p<0.05)$ to the predicted survival of the L. rhamnosus after drying, independent of encapsulating agent type (Table 3). The three-dimensional surface plot (Figure 1) shows that the survival of L. rhamnosus increased as the inlet air temperature was decreased from 130 to $90{ }^{\circ} \mathrm{C}$, and the concentration of CM and FM increased from 0.0 to $0.6 \%(\mathrm{w} / \mathrm{v})$ (Figure 1a), and 0.0 to $0.2 \%$ $(\mathrm{w} / \mathrm{v})$ (Figure 1b), respectively. Additionally, Figure 1c shows a minimum value for the survival of L. rhamnosus $(50.23 \%)$ obtained to $6.5 \%(\mathrm{w} / \mathrm{v})$ of INL at $130{ }^{\circ} \mathrm{C}$, where drying inlet air temperature significantly $(p<0.0001)$ influenced the response (Table 3$)$.

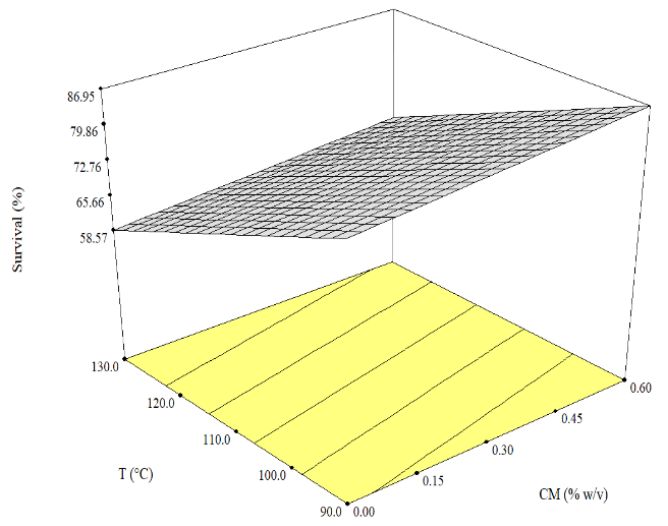

(a)

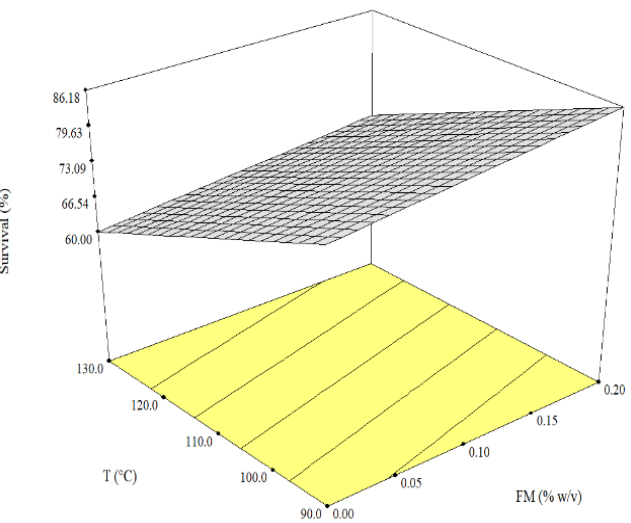

(b)

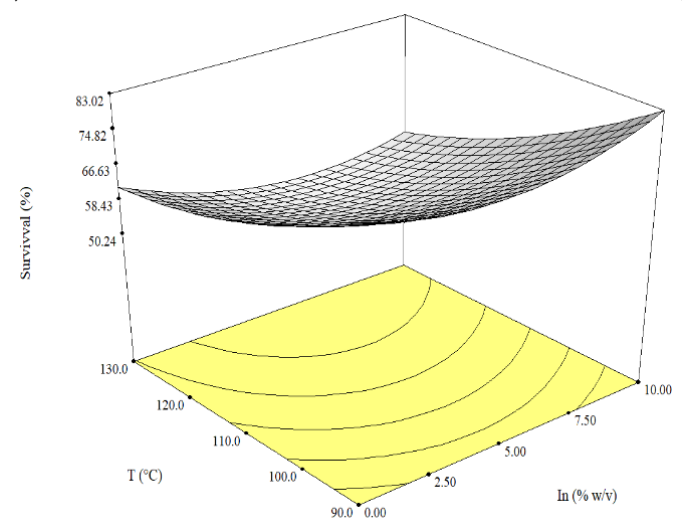

(c)

Figure 1. Three-dimensional surface plot for the survival of L. rhamnosus after spray drying. (a) Chia seed mucilage $(\mathrm{CM})$ and drying inlet air temperature $(\mathrm{T}),(\mathbf{b})$ Flaxseed mucilage $(\mathrm{FM})$ and drying inlet air temperature (T), (c) Inulin (INL) and drying inlet air temperature. 
Table 3. Summary of ANOVA for the overall effects of chia seed mucilage (CM), flaxseed mucilage (FM), or inulin (INL) concentration in the encapsulating solution and drying inlet air temperature (T) on the survival of the L. rhamnosus after spray drying.

\begin{tabular}{lllll}
\hline Factors & $\mathbf{D F}^{\mathbf{a}}$ & Mean Square & $\mathbf{F}_{\mathbf{e x p}} \mathbf{b}$ & $\boldsymbol{p}>\mathbf{F}$ \\
\hline $\mathrm{INL}$ & 1 & 12.40 & 1.95 & 0.2211 \\
$\mathrm{~T}$ & 1 & 895.19 & 140.99 & $<0.0001$ \\
$\mathrm{INL}^{2}$ & 1 & 114.07 & 17.97 & 0.0082 \\
$\mathrm{~T}^{2}$ & 1 & 34.70 & 5.46 & 0.0666 \\
$\mathrm{INL} \times \mathrm{T}$ & 1 & 25.07 & 3.95 & 0.1037 \\
\hline $\mathrm{CM}$ & 1 & 39.49 & 6.78 & 0.0314 \\
$\mathrm{~T}$ & 1 & 811.03 & 139.28 & $<0.0001$ \\
\hline $\mathrm{FM}$ & 1 & 44.55 & 2.97 & 0.1233 \\
$\mathrm{~T}$ & 1 & 645.01 & 42.95 & 0.0002 \\
\hline
\end{tabular}

${ }^{\mathrm{a}} \mathrm{DF}=$ Degree of freedom. ${ }^{\mathrm{b}} \mathrm{F}_{\exp }=$ Fisher ratio. Test for comparing model variance with residual variance.

Viability of the L. rhamnosus encapsulated with CM or without CM (control assay, only MD) decreased gradually during the first fourteen days of storage at $4{ }^{\circ} \mathrm{C}$ and then remained relatively constant (Figure 2). After one day of drying, viability of the L. rhamnosus encapsulated with $0.6 \%(\mathrm{w} / \mathrm{v})$ of $\mathrm{CM}$ and dried at $90^{\circ} \mathrm{C}$ (Figure 2c) was higher than the control (without $\mathrm{CM}$, Figure 2a) and with $0.3 \%(\mathrm{w} / \mathrm{v})$ of $\mathrm{CM}$ (Figure $2 \mathrm{~b}$ ). After 30 days, viability of the L. rhamnosus (Figure $2 \mathrm{~b}$ ) encapsulated with $0.3 \%(\mathrm{w} / \mathrm{v})$ of $\mathrm{CM}$ and dried at $90{ }^{\circ} \mathrm{C}$ showed an increase, which seems to be related to chain breakup; however, the reason for the apparent increase in the count under experimental conditions has not been determined [59]. After 40 days, the viability of L. rhamnosus in all the powders was greater than $6 \log$ $\mathrm{CFU} / \mathrm{g}$, and counts were higher than the levels recommended by the FAO/WHO [20] for probiotics to provide well-being and provide the consumer with health benefits. Furthermore, the highest viability of L. rhamnosus (9.26 log CFU/g) was obtained in powders with $0.6 \%(\mathrm{w} / \mathrm{v})$ of $\mathrm{CM}$ and $90{ }^{\circ} \mathrm{C}$ of inlet air temperature, counts higher than the levels required by the Italian Ministry of Health and Health Canada of the Government of Canada (9 log CFU) [60].

The effects of storage under refrigeration conditions $\left(4{ }^{\circ} \mathrm{C}\right)$ on the viability of L. rhamnosus encapsulated after 80 and 250 days are shown in Table 4. The count after 80 days varied from 6.39 to $9.12 \log \mathrm{CFU} / \mathrm{g}$, while after 250 days, it varied between 6.30 and $9.07 \log \mathrm{CFU} / \mathrm{g}$. Therefore, all the treatments showed counts higher than $6 \log \mathrm{CFU} / \mathrm{g}$, the minimum count recommended to offer consumer health benefits [20]. After 80 days of refrigerated storage, the viability of L. rhamnosus was significantly $(p<0.001)$ higher in the powders with $0.6 \%(\mathrm{w} / \mathrm{v})$ of $\mathrm{CM}$ and dried at $90^{\circ} \mathrm{C}$. On the other hand, after 250 days of storage at $4{ }^{\circ} \mathrm{C}$, the viability was significantly $(p<0.001)$ higher in powders with 0.3 and $0.6 \%(\mathrm{w} / \mathrm{v})$ dried at $90^{\circ} \mathrm{C}$.

Table 4. Effect of the encapsulating solution (ES) composition and drying inlet air temperature (T) in spray drying on viability of L. rhamnosus after 80 and 250 days of storage at $4{ }^{\circ} \mathrm{C}$.

\begin{tabular}{|c|c|c|c|c|}
\hline \multirow{2}{*}{$\mathrm{T}\left({ }^{\circ} \mathrm{C}\right)$} & \multicolumn{2}{|c|}{ Composition ES $(\% \mathrm{w} / \mathrm{v})$} & \multicolumn{2}{|c|}{ Viability (log CFU/g) } \\
\hline & $\mathrm{MD}^{+}$ & $\mathrm{CM}^{+}$ & Day 80 & Day 250 \\
\hline \multirow[t]{3}{*}{90} & 15 & 0 & $7.82 \pm 0.25^{c}$ & $7.77 \pm 0.11^{b}$ \\
\hline & 14.7 & 0.3 & $8.76 \pm 0.05^{\mathrm{ab}}$ & $8.72 \pm 0.04^{a}$ \\
\hline & 14.4 & 0.6 & $9.12 \pm 0.11^{\text {a }}$ & $9.07 \pm 0.12^{\mathrm{a}}$ \\
\hline \multirow[t]{3}{*}{110} & 15 & 0 & $7.63 \pm 0.33^{c}$ & $7.43 \pm 0.28^{b}$ \\
\hline & 14.7 & 0.3 & $7.51 \pm 0.33^{c}$ & $7.29 \pm 0.26^{b}$ \\
\hline & 14.4 & 0.6 & $8.02 \pm 0.24 b c$ & $7.67 \pm 0.04^{b}$ \\
\hline \multirow[t]{3}{*}{130} & 15 & 0 & $6.39 \pm 0.14^{\mathrm{e}}$ & $6.33 \pm 0.17^{c}$ \\
\hline & 14.7 & 0.3 & $6.48 \pm 0.24 \mathrm{de}$ & $6.60 \pm 0.12^{c}$ \\
\hline & 14.4 & 0.6 & $7.29 \pm 0.16^{\mathrm{cd}}$ & $6.30 \pm 0.10^{c}$ \\
\hline
\end{tabular}

${ }^{+}$MD: Maltodextrin; CM: Chia seed mucilage. Different letters in the same column indicate significant differences by Tukey's one-way analysis of variance $(p<0.05)$. 
The results observed in this study on the enhanced survival and viability of the L. rhamnosus encapsulated with $0.6 \%(\mathrm{w} / \mathrm{v})$ of $\mathrm{CM}$ suggest that this chia seed component would act as a thermoprotector of cells undergoing the drying process and storage. The protein $(14.43 \%)$ content of $\mathrm{CM}$ reported in this study was similar to those reported by Bustamante et al. [52] and Felisberto et al. [61], who determined that CM presented a high-protein-soluble concentration, 11.62 and $13.71 \mathrm{~g} / 100 \mathrm{~g}$ dry weight, respectively. On the other hand, Sandoval-Oliveros and Paredes-López [62] determined that the chia seed proteins are mainly constituted by globular proteins $(52 \%)$. Furthermore, it has been shown that the soluble fiber of chia seed and the proteins (denatured due to the encapsulation solution sterilization and the effect of the drying inlet air temperature) present in mucilage may increase the water holding capacity, enhancing the swelling ability [63], which would afford the bacteria greater protection. On the other hand, the globulins exhibit poor mechanical properties because the hydrophobic and SH groups are buried inside the molecule. Drying temperature produces protein denaturation, changing its native structure, allowing protein-protein interactions, disulfide cross-linking, and hydrogen-boding; these interactions make the denatured protein stiffer, stronger, and stretchable, which would better protect the cells [52,64].

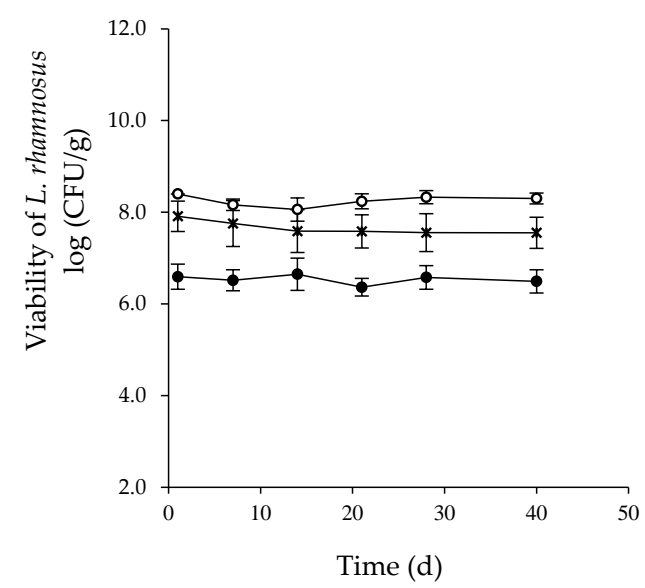

(a)

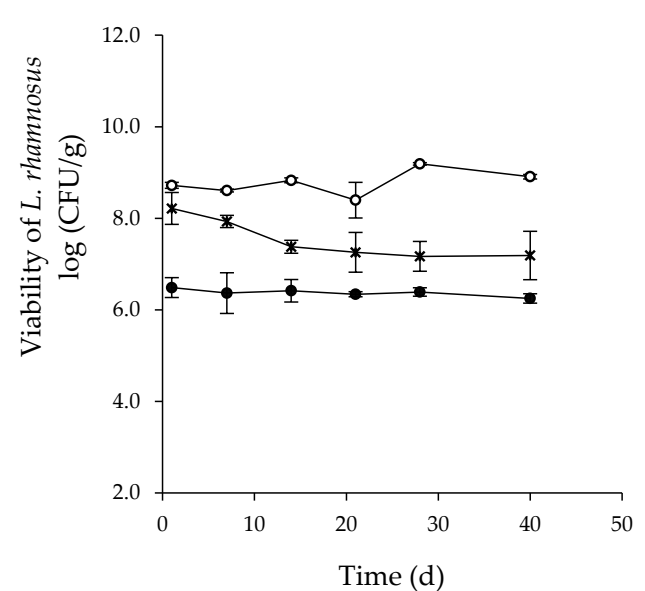

(b)

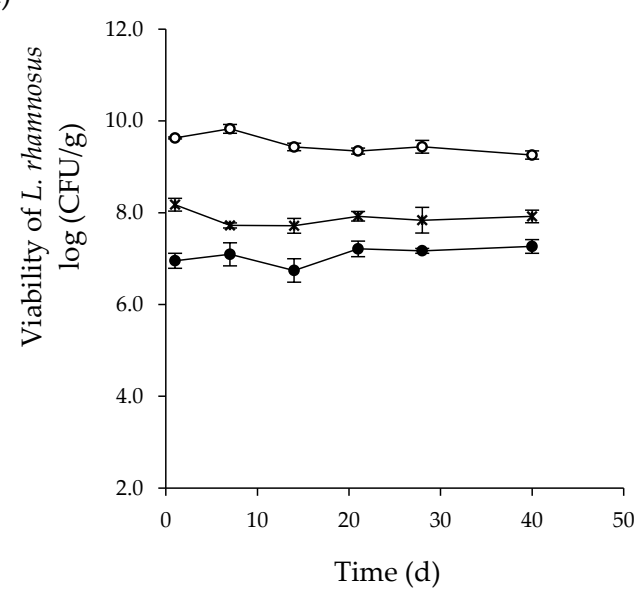

(c)

Figure 2. Viability of L. rhamnosus encapsulated by spray drying with different concentrations of chia seed mucilage $(\mathrm{CM})$ during storage at $4{ }^{\circ} \mathrm{C}$. (a) Control without the $\mathrm{CM}$, (b) $0.3 \% \mathrm{w} / \mathrm{v}$ of $\mathrm{CM}$, and (c) $0.6 \% \mathrm{w} / \mathrm{v}$ of $\mathrm{CM}$. Drying inlet air temperature $(\bigcirc) 90^{\circ} \mathrm{C},(\bullet) 110{ }^{\circ} \mathrm{C}$, and $(*) 130{ }^{\circ} \mathrm{C}$.

The residual moisture content is an important factor not only for maintaining the viability of microencapsulated microorganisms, but also for handling, storage, packaging, and transportation, among others [65]. In this assay, the moisture content (Table 2) varied between 2.20 and 6.53\%. These low 
values show the production spray-dried powders with good manipulation characteristics, stable due to the lower amount of water available for chemical reactions, probiotics viability, and stability of the product during storage, among others.

\subsection{Effect of Spray Drying on the Survival of L. plantarum and Strains of the Genus Bifidobacterium and Viability during Storage}

The operating conditions $\left(0.6 \% \mathrm{w} / \mathrm{v}\right.$ of $\mathrm{CM}$ at $\left.90^{\circ} \mathrm{C}\right)$ that maximize the survival of $L$. rhamnosus were applied for encapsulating L. plantarum, B. infantis, and B. longum (probiotic bacteria commonly found in the human gastrointestinal tract and present in many dairy products and functional foods). Cell damage and activity loss may occur during processing, and also during storage of the dehydrated cells. Thus, the encapsulation process should ensure that the microorganisms survive processing, as well as maintain their viability during storage. In this context, viability during storage at 4 and $25^{\circ} \mathrm{C}$ was evaluated for 60 days. The survival of different probiotic bacteria after drying (Table 5) was greater than 90\% (L. rhamnosus, 91.23\%; L. plantarum, 94.77\%; B. longum, 96.07\%; and B. infantis, 97.24\%). The high probiotic bacteria survival suggests that $C M$ thermoprotected cell inactivation during spray drying, avoiding damage to the membrane, ribosome, DNA, and protein [33,34]. On the other hand, the fiber $(2.35 \%)$ content of CM may offer different degrees of protection to the cell and act as a gelling agent, increasing encapsulating efficiency and microcapsule stability. Other factors that could also explain this high survival are strain growth phase (late-log phase or start-stationary phase) during spray drying and the intrinsic tolerance of strains to heat. In this study, probiotic bacteria were harvested in the late-log phase, the stage in which spray drying causes low cell damage, and a high number of viable cells is obtained after drying. Teixeira et al. [66] determined that stationary phase cultures were more resistant to heat than exponential phase cultures, while Corcoran et al. [26] determined that the stationary phase was most suitable for microencapsulation by spray drying. Moreover, the survival of the Bifidobacterium species after spray drying is dependent on the kinds of carrier [67] and varies with the strains because some have a distinctive tolerance to heat [54]. In this assay, the moisture content of powders varied between 2.95 and $5.77 \%$ (Table 4), values that ensure the fluidity and stability of the product and avoid its agglomeration [65].

Table 5. Survival of probiotic strains encapsulated by spray drying with chia seed mucilage $(0.6 \% \mathrm{w} / \mathrm{v})$ at $90{ }^{\circ} \mathrm{C}$ and moisture content after spray drying.

\begin{tabular}{|c|c|c|}
\hline Probiotic Strain & Survival $^{+}(\%)$ & Moisture $^{+\dagger}(\%)$ \\
\hline L. rhanmosus & $91.23 \pm 2.88^{a}$ & $2.95 \pm 0.17$ \\
\hline L. plantarum ATCC 8014 & $94.77 \pm 1.95^{\mathrm{a}}$ & $3.52 \pm 0.18$ \\
\hline B. infantis ATCC 15679 & $97.24 \pm 2.32^{a}$ & $5.77 \pm 0.20$ \\
\hline B. longum АТCC 15707 & $96.07 \pm 0.07^{\mathrm{a}}$ & $4.70 \pm 0.41$ \\
\hline
\end{tabular}

Same letters in the same column indicate not significantly different $(p<0.05)$ according to Tukey's test. ${ }^{+}$Mean values of two replicates. ${ }^{+\dagger}$ Mean values of four replicates.

All spray-dried microcapsules containing probiotic bacteria show high viability for a period of 60 days of storage at $4{ }^{\circ} \mathrm{C}$ (Figure 3). The initial counts of probiotics varied between $10.50 \pm 0.10$ and $9.64 \pm 0.08 \log \mathrm{CFU} / \mathrm{g}$ for B. infantis and L. rhamnosus, respectively. Then, after 60 days of storage, the counts varied between $10.04 \pm 0.13$ and $8.46 \pm 0.25 \mathrm{log} C F U / g$, for the same probiotic strains, values above the recommended levels for probiotic food throughout the storage time, i.e., equal to or greater than $6 \log C F U / g$ of the product $[20,68]$. In addition, the viability of microcapsules containing L. plantarum, B. infantis, or B. longum, stored after 60 days at $4{ }^{\circ} \mathrm{C}$ (Figure 3a), was significantly $(p<0.05)$ greater than the viability of $L$. rhamnosus. The high viability values obtained for all probiotic bacteria can be explained by a decrease in their metabolic activity when stored at refrigeration temperatures. On the other hand, during storage of the microcapsules at $25^{\circ} \mathrm{C}$, a continuous decrease was noted in the viability of the four probiotics (Figure 3b). The initial counts of probiotics varied between $10.24 \pm 0.31$ and $9.45 \pm 0.17 \log \mathrm{CFU} / \mathrm{g}$ for B. infantis and L. plantarum, respectively. However, L. rhamnosus lost 
its viability drastically after 28 days. Meanwhile, after 60 days of storage, viability of B. longum, L. plantarum, and B. infantis reached counts of $1.70 \pm 0.08,5.53 \pm 0.20$, and $6.45 \pm 0.23 \log \mathrm{CFU} / \mathrm{g}$, respectively. In this context, $B$. infantis and L. plantarum are more stable than $B$. longum and L. rhamnosus at $25^{\circ} \mathrm{C}$. These results, compared to counts at $4{ }^{\circ} \mathrm{C}$, represent a loss in viability for B. longum, L. plantarum, and B. infantis of 83,44 , and $36 \%$, respectively. The reduction in the number of viable probiotics stored at $25{ }^{\circ} \mathrm{C}$ can be explained because at this temperature, the metabolic activity is higher and nutrients are consumed quickly [69]. A solution to protect the viability of probiotic bacteria during storage is to perform double encapsulation, where the outer layer has a protective function and the inner layer a nutritional function.

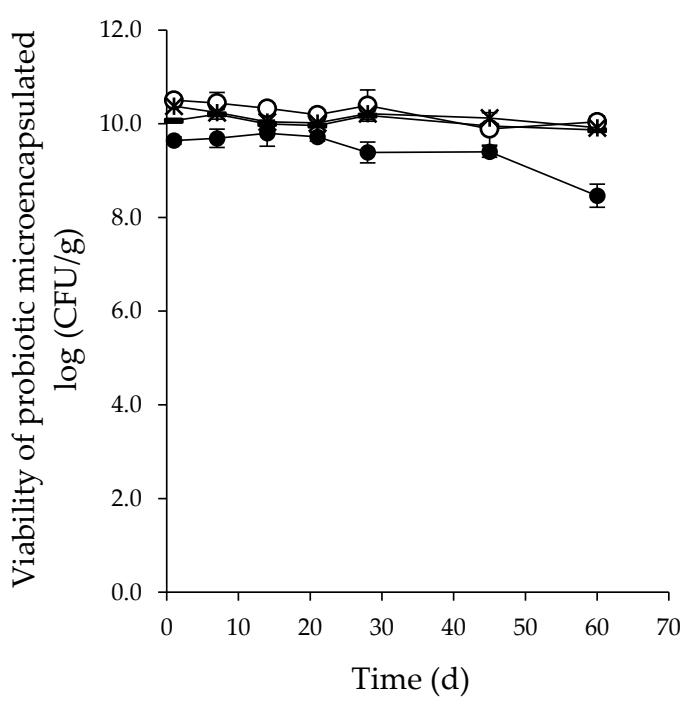

(a)

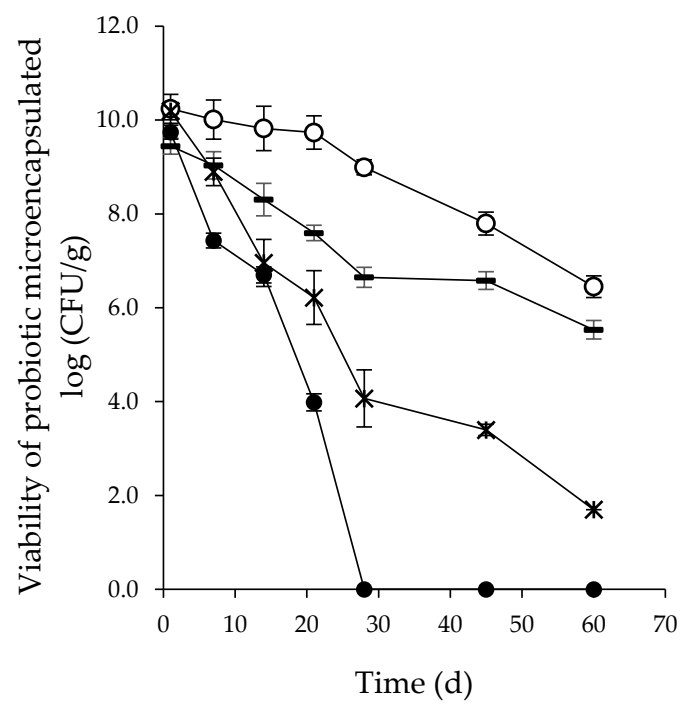

(b)

Figure 3. Viability during storage of probiotics encapsulated by spray drying with $0.6 \% \mathrm{w} / \mathrm{v}$ of chia seed mucilage $(\mathrm{CM})$ in the encapsulating solution at $90{ }^{\circ} \mathrm{C}$ : (a) $4{ }^{\circ} \mathrm{C}$ and (b) $25^{\circ} \mathrm{C}$. (-) L. plantarum, (०) B. infantis, (*) B. longum, and $(\bullet)$ L. rhamnosus.

\subsection{Characterization of the Spray-Dried Product}

Figure 4 shows the SEM images of spray-dried particles containing probiotic bacteria encapsulated with $0.6 \% \mathrm{w} / \mathrm{v}$ of $\mathrm{CM}$ at $90{ }^{\circ} \mathrm{C}$, stored for 1 day at $4{ }^{\circ} \mathrm{C}$. The particles of all the four groups show a spherical shape and assorted sizes, varying between 1.77 and $15.5 \mu \mathrm{m}$, with concavities typical of materials produced by spray drying due to the shrinkage of the particles because of the rapid evaporation of the liquid drops [70]. Additionally, the SEM micrographs revealed that the external surface of the dry particles is free of fissure or disruption; entrapped cells are not visible in powder. 


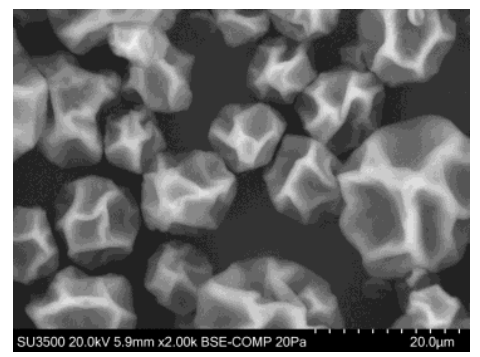

(a)

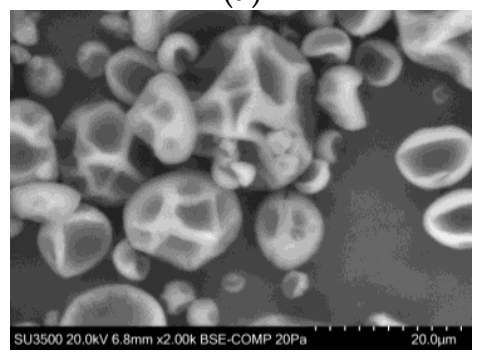

(c)

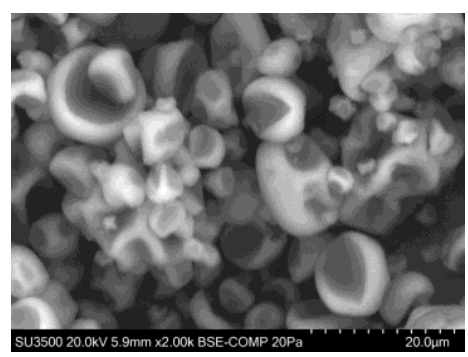

(b)

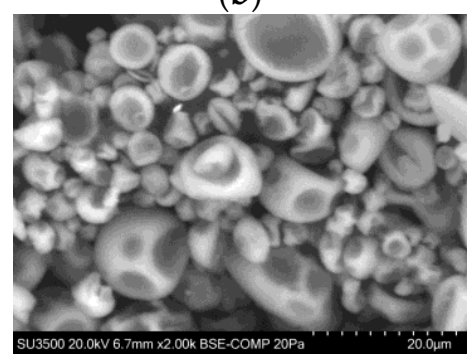

(d)

Figure 4. Scanning electron microscopy images of spray-dried particles containing probiotics stored for 1 day at $4{ }^{\circ} \mathrm{C}$. The spray-drying process was conducted with an encapsulating solution that contained maltodextrin $(14.4 \% \mathrm{w} / \mathrm{v})$ and chia seed mucilage $(0.6 \% \mathrm{w} / \mathrm{v})$ and dried with an inlet air temperature of $90^{\circ}$ C. (a) L. rhamnosus, (b) L. plantarum, (c) B. infantis, and (d) B. longum.

\section{Conclusions}

Our results show that the survival of L. rhamnosus encapsulated by spray drying was negatively affected by the inlet air temperature, an effect that can be reduced when chia seed mucilage, flaxseed mucilage, or inulin were incorporated into the encapsulation solution. The optimal conditions of encapsulation $\left(0.6 \% \mathrm{w} / \mathrm{v}\right.$ of $\mathrm{CM} ; 14.4 \% \mathrm{w} / \mathrm{v}$ of $\left.\mathrm{MD} ; 90^{\circ} \mathrm{C}\right)$ improve the survival and viability of probiotics, achieving counts higher than recommended to exert consumer health benefits. Optimum encapsulation conditions allowed promising survival values $(>91 \%)$ during spray drying and viability $(>8.5 \log \mathrm{CFU} / \mathrm{g})$ during storage under refrigeration conditions $\left(4^{\circ} \mathrm{C}\right)$ of L. plantarum, B. infantis, and B. longum. The high viscosity of the aqueous solution of chia seed mucilage restricts its concentration in the encapsulation solution by spray drying. However, these results show the potential of chia seed mucilage to thermoprotect the integrity of probiotic cells against processing and storage conditions, which ensure an optimal probiotic efficacy in the end product. The incorporation of probiotic cells into food matrices is not easy, due to the wide range of detrimental processes that take place during food processing and storage. In this context, the results of this study can be used as a reference by the food industry, as the incorporation of chia seed mucilage as an encapsulating agent for probiotic cells by spray drying is a strategy that would surpass the obstacles related to the probiotics' lethality due to food processing and storage.

Author Contributions: Formal analysis, L.L.-M.; Investigation, M.B.; Resources, C.S.; Supervision, M.R.; Visualization, D.V. and R.C.-V.; Writing-original draft, M.B. All authors have read and agree to the published version of the manuscript.

Funding: This research was supported by the Agencia Nacional de Investigación y Desarrollo (ANID) through FONDECYT project No. 11160249. This research was funded (partially) by the Dirección de Investigación, Universidad de La Frontera, Chile.

Acknowledgments: We also acknowledge the support of Dirección de Investigación provided through GAP and to Helen Lowry for her support in editing the English in the manuscript.

Conflicts of Interest: The authors declare no conflict of interest. 


\section{References}

1. Mordor Intelligence. Probiotics Market-Growth, Trends and Forecasts (2018-2023). 2018. Available online: https://www.researchandmarkets.com/reports/4663724/probiotics-market-growth-trendsand-forecasts (accessed on 1 December 2018).

2. Mordor Intelligence. Probiotics Market-Growth, Trends and Forecasts (2019-2024). 2019. Available online: https:/www.researchandmarkets.com/reports/4771770/probiotics-market-growth-trendsand-forecasts (accessed on 26 September 2019).

3. Bustamante, M.; Oomah, B.D.; Oliveira, W.P.; Burgos-Díaz, C.; Rubilar, M.; Shene, C. Probiotics and prebiotics potential for the care of skin, female urogenital tract, and respiratory tract. Folia Microbiol. 2019, 65, $245-264$. [CrossRef]

4. Nagpal, R.; Kumar, A.; Kumar, M.; Behare, P.V.; Jain, S.; Yadav, H. Probiotics, their health benefits and applications for developing healthier foods: A review. FEMS Microbiol. Lett. 2012, 334, 1-15. [CrossRef] [PubMed]

5. Oyetayo, V.O. Phenotypic characterization and assessment of the inhibitory potential of lactobacillus isolates from different sources. Afr. J. Biotechnol. 2004, 3, 355-357. [CrossRef]

6. Gu, R.X.; Yang, Z.Q.; Li, Z.H.; Chen, S.L.; Luo, Z.L. Probiotic properties of lactic acid bacteria isolated from stool samples of longevous people in regions of Hotan, Xinjiang and Bama, Guangxi, China. Anaerobe 2008, 14, 313-317. [CrossRef]

7. Zheng, J.; Wittouck, S.; Salvetti, E.; Franz, C.M.A.P.; Harris, H.M.B.; Mattarelli, P.; O’Toole, P.W.; Pot, B.; Vandamme, P.; Walter, J.; et al. A taxonomic note on the genus Lactobacillus: Description of 23 novel genera, emended description of the genus Lactobacillus Beijerinck 1901, and union of Lactobacillaceae and Leuconostocaceae. Int. J. Syst. Evol. Micr. 2020, 70, 2782-2858. [CrossRef]

8. Forestier, C.; De Champs, C.; Vatoux, C.; Joly, B. Probiotic activities of Lactobacillus casei rhamnosus: In vitro adherence to intestinal cells and antimicrobial properties. Res. Microbiol. 2001, 152, 167-173. [CrossRef]

9. Bu, L.N.; Chang, M.H.; Ni, Y.H.; Chen, H.L.; Cheng, C.C. Lactobacillus casei rhamnosus Lcr35 in children with chronic constipation. Pediatr. Int. 2007, 49, 485-490. [CrossRef]

10. Forestier, C.; Guelon, D.; Cluytens, V.; Gillart, T.; Sirot, J.; De Champs, C. Oral probiotic and prevention of Pseudomonas aeruginosa infections: A randomized, double-blind, placebo-controlled pilot study in intensive care unit patients. Crit. Care. 2008, 12, R69. [CrossRef]

11. Kovachev, S.; Dobrevski-Vacheva, R. Effect of Lactobacillus casei var rhamnosus (Gynophilus) in restoring the vaginal flora by female patients with bacterial vaginosis-randomized, open clinical trial. Akush. Ginekol. (Sofiia) 2013, 52, 48-53.

12. Lash, B.W.; Mysliwiec, T.H.; Gourama, H. Detection and partial characterization of a broad-range bacteriocin produced by Lactobacillus plantarum (ATCC 8014). Food Microbiol. 2005, 22, 199-204. [CrossRef]

13. Vahedi Shahandashti, R.; Kasra Kermanshahi, R.; Ghadam, P. The inhibitory effect of bacteriocin produced by Lactobacillus acidophilus ATCC 4356 and Lactobacillus plantarum ATCC 8014 on planktonic cells and biofilms of Serratia marcescens. Turk. J. Med. Sci. 2016, 46, 1188-1196. [CrossRef] [PubMed]

14. Monteiro, C.R.A.V.; do Carmo, M.S.; Melo, B.O.; Alves, M.S.; dos Santos, C.I.; Monteiro, S.G.; Bomfim, M.R.Q.Q.; Fernandes, E.S.; Monteiro-Neto, V. In vitro antimicrobial activity and probiotic potential of Bifidobacterium and Lactobacillus against species of Clostridium. Nutrients 2019, 11, 448. [CrossRef]

15. Lee, J.H.; O'Sullivan, D.J. Genomic insights into Bifidobacteria. Microbiol. Mol. Biol. Rev. 2010, 74, 378-416. [CrossRef]

16. Arboleya, S.; Watkins, C.; Stanton, C.; Ross, P. Gut bifidobacteria populations in human health and aging. Front. Microbiol. 2016, 7, 1-9. [CrossRef] [PubMed]

17. Yung, B.; Song, M.; Park, D.J.; Oh, S. Beneficial effect of Bifidobacterium longum ATCC 15707 on survival rate of Clostridium difficile infection in mice. Korean J. Food Sci. Anim. Resour. 2017, 37, 368-375. [CrossRef]

18. Rodrigues, F.C.; Castro, A.S.B.; Rodrigues, V.C.; Fernandes, S.A.; Fontes, E.A.F.; de Oliveira, T.T.; Martino, H.S.D.; de Luces Fortes Ferreira, C.L. Yacon flour and Bifidobacterium longum modulate bone health in rats. J. Med. Food 2012, 15, 664-670. [CrossRef]

19. Sheng, K.; He, S.; Sun, M.; Zhang, G.; Kong, X.W.; Wang, J.; Wang, Y. Synbiotic supplementation containing Bifidobacterium infantis and xylooligosaccharide alleviates dextran sulfate sodium-induced ulcerative colitis. Food Funct. 2020, 11, 3964-3974. [CrossRef] 
20. FAO/WHO. Guidelines for the Evaluation of Probiotics in Food. Food and Agriculture Organization of the United Nations/World Health Organization. London, Ontario, Canada. 2002. Available online: https://www.who.int/foodsafety/fs_management/en/probiotic_guidelines.pdf (accessed on 16 May 2019).

21. Desmond, C.; Ross, R.P.; O'Callaghan, E.; Fitzgerald, G.; Stanton, C. Improved survival of Lactobacillus paracasei NFBC 338 in spray-drying powders containing gum acacia. J. Appl. Microbiol. 2002, 9, 1003-1011. [CrossRef]

22. Bustamante, M.; Oomah, B.D.; Rubilar, M.; Shene, C. Effective Lactobacillus plantarum and Bifidobacterium infantis encapsulation with chia seed (Salvia hispanica L.) and flaxseed (Linum usitatissimum L.) mucilage and soluble protein by spray drying. Food Chem. 2017, 216, 97-105. [CrossRef]

23. Guerin, J.; Petit, J.; Burgain, J.; Borges, F.; Bhandari, B.; Perroud, C.; Desobry, S.; Scher, J.; Gaiani, C. Lactobacillus rhamnosus GG encapsulation by spray-drying: Milk proteins clotting control to produce innovative matrices. J. Food Eng. 2017, 193, 10-19. [CrossRef]

24. Favaro-Trindade, C.S.; Grosso, C.R.F. Microencapsulation of L. acidophilus (La-05) and B. lactis (Bb-12) and evaluation of their survival at the $\mathrm{pH}$ values of the stomach and in bile. J. Microencapsul. 2002, 19, 485-494. [CrossRef]

25. Fritzen-Freire, C.B.; Prudêncio, E.S.; Amboni, R.D.M.C.; Pinto, S.S.; Negrão-Murakami, A.N.; Murakami, F.S. Microencapsulation of bifidobacteria by spray drying in the presence of prebiotics. Food Res. Int. 2012, 45, 306-312. [CrossRef]

26. Corcoran, B.M.; Ross, R.P.; Fitzgerald, G.F.; Stanton, C. Comparative survival of probiotic lactobacilli spray-dried in the presence of prebiotic substances. J. Appl. Microbiol. 2004, 96, 1024-1039. [CrossRef]

27. Sunny-Roberts, E.O.; Knorr, D. Cellular injuries on spray-dried Lactobacillus rhamnosus GG and its stability during food storage. Nutr. Food Sci. 2011, 41, 191-200. [CrossRef]

28. Teixeira, P.; Castro, H.; Kirby, R. Inducible thermotolerance in Lactobacillus bulgaricus. Lett. Appl. Microbiol. 1994, 18, 218-221. [CrossRef]

29. Chlebowska-Smigiel, A.; Gniewosz, M.; Kieliszek, M.; Bzducha-Wrobel, A. The effect of pullulan on the growth and acidifying activity of selected stool microflora of human. Curr. Pharm. Biotechnol. 2017, 18, 121-126. [CrossRef]

30. Çabuk, B.; Harsa, Ş. Whey protein-pullulan (WP/Pullulan) polymer blend for preservation of viability of Lactobacillus acidophilus. Dry. Technol. 2015, 33, 1223-1233. [CrossRef]

31. Anekella, K.; Orsat, V. Optimization of microencapsulation of probiotics in raspberry juice by spray drying. LWT Food Sci. Technol. 2013, 50, 17-24. [CrossRef]

32. Paim, D.R.S.F.; Costa, S.D.O.; Walter, E.H.M.; Tonon, R.V. Microencapsulation of probiotic jussara (Euterpe edulis M.) juice by spray drying. LWT Food Sci. Technol. 2016, 74, 21-25. [CrossRef]

33. Rodríguez-Huezo, M.E.; Durán-Lugo, R.; Prado-Barragán, L.A.; Cruz-Sosa, F.; Lobato-Calleros, C.; Alvarez-Ramírez, J.; Vernon-Carter, E.J. Pre-selection of protective colloids for enhanced viability of Bifidobacterium bifidum following spray-drying and storage, and evaluation of aguamiel as thermoprotective prebiotic. Food Res. Int. 2007, 40, 1299-1306. [CrossRef]

34. Rajam, R.; Anandharamakrishnan, C. Spray freeze drying method for microencapsulation of Lactobacillus plantarum. J. Food Eng. 2015, 166, 95-103. [CrossRef]

35. Ross, R.P.; Desmond, C.; Fitzgerald, G.F.; Stanton, C. A Review. Overcoming the technological hurdles in the development of probiotics foods. J. Appl. Microbiol. 2005, 98, 1410-1417. [CrossRef]

36. Sosa, N.; Gerbino, E.; Golowczyc, M.A.; Schebor, C.; Gómez-Zavaglia, A.; Tymczyszyn, E.E. Effect of galacto-oligosaccharides: Maltodextrin matrices on the recovery of Lactobacillus plantarum after spary-drying. Front. Microbiol. 2016, 7, 1-8. [CrossRef]

37. Apolinário, A.C.; de Lima Damasceno, B.P.G.; de Macêdo Beltrão, N.E.; Pessoa, A.; Converti, A.; da Silva, J.A. Inulin-type fructans: A review on different aspects of biochemical and pharmaceutical technology. Carbohydr. Polym. 2014, 101, 368-378. [CrossRef] [PubMed]

38. Shoaib, M.; Shehzad, A.; Omar, M.; Rakha, A.; Raza, H.; Sharif, H.R.; Shakeel, A.; Ansari, A.; Niazi, S. Inulin: Properties, health benefits and food applications. Carbohydr. Polym. 2016, 147, 444-454. [CrossRef] [PubMed]

39. Shim, Y.Y.; Gui, B.; Arnison, P.G.; Wang, Y.; Reaney, M.J.T. Flaxseed (Linum usitatissimum L.) bioactive compounds and peptide nomemclature: A review. Trends Food Sci. Tech. 2014, 38, 5-20. [CrossRef]

40. Mazza, G.; Biliaderis, C.G. Functional properties of flax seed mucilage. J. Food Sci. 1989, 5, $1302-1305$. [CrossRef] 
41. Naran, R.; Chen, G.; Carpita, N.C. Novel Rhamnogalacturonan I and Arabinoxylan polysaccharides of flax seed mucilage. Plant. Physiol. 2008, 148, 132-141. [CrossRef]

42. Wanasundara, P.K.J.P.D.; Shahidi, F. Removal of flaxseed mucilage by chemical and enzymatic treatments. Food Chem. 1997, 59, 47-55. [CrossRef]

43. Warrand, J.; Michaud, P.; Picton, L.; Muller, G.; Courtis, B.; Ralainirina, R.; Courtois, J. Structural investigations of the neutral polysaccharide of Linum usitatissimum L. seeds mucilage. Int. J. Biol. Macromol. 2005, 35, 121-125. [CrossRef]

44. Chen, H.; Xu, S.; Wang, Z. Gelation properties of flaxseed gum. J. Food Eng. 2006, 77, 295-303. [CrossRef]

45. Thakur, G.; Mitra, A.; Pal, K.; Rousseau, D. Effect of flaxseed gum on reduction of blood glucose and cholesterol in type 2 diabetic patients. Int. J. Food Sci. Nutr. 2009, 60, 126-136. [CrossRef]

46. Brahe, L.K.; Le Chatelier, E.; Prifti, E.; Pons, N.; Kennedy, S.; Blædel, T.; Håkansson, J.; Dalsgaard, T.K.; Hansen, T.; Pedersen, O.; et al. Dietary modulation of the gut microbiota-a randomised controlled trial in obese postmenopausal women. Br. J. Nutr. 2015, 114, 406-417. [CrossRef] [PubMed]

47. Kristensen, M.; Savorani, F.; Christensen, S.; Engelsen, S.B.; Bugel, S.; Toubro, S.; Tetens, I.; Astrup, A. Flaxseed dietary fibers suppress postprandial lipemia and apetite sensation in young men. Nutr. Metab. Cardiovasc. Dis. 2013, 23, 136-143. [CrossRef]

48. Ullah, R.; Nadeem, M.; Khalique, A.; Imran, M.; Mehmood, S.; Javid, A.; Hussain, J. Nutritional and therapeutic perspectives of Chia (Salvia hispanica L.): A review. J. Food Sci. Technol. 2016, 53, 1750-1758. [CrossRef]

49. Commission Implementing Regulation (EU) 2017/2470. Establishing the Union List of Novel Foods in accordance with Regulation (EU) 2015/2283 of the European Parliament and of the Council on novel foods. 2017. Available online: https://eur-lex.europa.eu/legal-content/EN/TXT/?uri=CELEX\%3A32017R2470 (accessed on 1 April 2020).

50. Lin, K.Y.; Daniel, J.R.; Whistler, R.L. Structure of chia seed polysaccharide exudate. Carbohydr. Polym. 1994, 23, 13-18. [CrossRef]

51. BeMiller, J.N.; Whistler, R.L.; Barkalow, D.G.; Chen, C.C. Chapter 9-Aloe, chia, flaxseed, okra, psyllium seed, quince seed, and tamarind gums. In Industrial Gums: Polysaccharides and Their Derivatives, 3rd ed.; Whistler, R.L., BeMiller, J.N., Eds.; Academic Press. Inc.: San Diego, CA, USA, 1993; pp. 227-256. [CrossRef]

52. Bustamante, M.; Villarroel, M.; Rubilar, M.; Shene, C. Lactobacillus acidophilus La-05 encapsulated by spray drying: Effect of mucilage and protein from flaxseed (Linum usitatissimum L.). LWT Food Sci. Technol. 2015, 62, 1162-1168. [CrossRef]

53. AOAC. Official Methods of Analysis of AOAC International, 16th ed.; AOAC Inc.: Gaithersburg, MD, USA, 1995.

54. Simpson, P.J.; Stanton, C.; Fitzgerald, G.F.; Ross, R.P. Intrinsic tolerance of Bifidobacterium species to heat and oxygen and survival following spray drying and storage. J. Appl. Microbiol. 2005, 99, 493-501. [CrossRef] [PubMed]

55. IDF. Dried milk and dried cream: Determination of water content. International Dairy Federation standard 26A. In International Dairy Federation; IDF: Brussels, Belgium, 1993.

56. Timilsena, Y.P.; Adhikari, R.; Kasapis, S.; Adhikari, B. Molecular and functional characteristics of purified gum from Australian chia seeds. Carbohydr. Polym. 2016, 136, 128-136. [CrossRef]

57. Maskan, M.; Gogus, F. Effect of sugar on the rheological properties of sunflower oil-water emulsions. J. Food Eng. 2000, 43, 173-177. [CrossRef]

58. Hernández-López, Z.; Rangel-Vargas, E.; Castro-Rosas, J.; Gómez-Aldapa, C.A.; Cadena-Ramírez, A.; Acevedo-Sandoval, O.A.; Gordillo-Martínez, A.J.; Falfán-Cortés, R.N. Optimization of a spray-drying process for the production of maximally viable microencapsulated Lactobacillus pentosus using a mixture of starch-pulque as wall material. LWT Food Sci. Technol. 2018, 95, 216-222. [CrossRef]

59. De Lara Pedroso, D.; Thomazini, M.; Heinemann, R.J.B.; Favaro-Trindade, C.S. Protection of Bifidobacterium lactis and Lactobacillus acidophilus by microencapsulation using spray-chilling. Int. Dairy J. 2012, 26, 127-132. [CrossRef]

60. Hill, C.; Guarner, F.; Reid, G.; Gibson, G.R.; Merenstein, D.J.; Pot, B.; Morelli, L.; Canani, R.B.; Flint, H.J.; Salminen, S.; et al. Expert consensus document: The International Scientific Association for Probiotics and Prebiotics consensus statement on the scope and appropriate use of the term probiotic. Nat. Rev. Gastroenterol. Hepatol. 2014, 11, 506-514. [CrossRef] 
61. Felisberto, M.H.F.; Wahanik, A.L.; Gomes-Ruffi, C.R.; Clerici, M.T.P.S.; Chang, Y.K.; Steel, C.J. Use of chia (Salvia hispanica L.) mucilage gel to reduce fat in pound cakes. LWT Food Sci. Technol. 2015, 63, 1049-1055. [CrossRef]

62. Sandoval-Oliveros, M.R.; Paredes-López, O. Isolation and characterization of proteins from chia seeds (Salvia hispanica L.). J. Agric. Food Chem. 2013, 61, 193-201. [CrossRef] [PubMed]

63. Segura-Campos, M.R.; Ciau-Solís, N.; Rosado-Rubio, G.; Chel-Guerrero, L.; Betancur-Ancona, D. Chemical and functional properties of chia seed (Salvia hispanica L.) gum. Int. J. Food Sci. 2014, 2014, 1-5. [CrossRef]

64. Li-Chan, E.C.Y.; Ma, C.Y. Thermal analysis of flaxseed (Linum usitatissimum) proteins by differential scanning calorimetry. Food Chem. 2002, 77, 495-502. [CrossRef]

65. Jung, H.; Lee, Y.; Yoon, W. Effect of moisture content on the grinding process and powder properties in food: A review. Processes 2018, 6, 69. [CrossRef]

66. Teixeira, P.; Castro, H.; Kirby, R. Spray drying as a method for preparing concentrated cultures of Lactobacillus bulgaricus. J. Appl. Bacteriol. 1995, 78, 456-462. [CrossRef]

67. Lian, W.C.; Hsiao, H.C.; Chou, C.C. Survival of bifidobacterial after spray-drying. Int. J. Food Microbiol. 2002, 74, 79-86. [CrossRef]

68. Shah, N.P. Functional cultures and health benefits. Int. Dairy J. 2007, 17, 1262-1277. [CrossRef]

69. Ávila-Reyes, S.V.; Garcia-Suarez, F.J.; Jiménez, M.T.; San Martín-Gonzalez, M.F.; Bello-Perez, L.A. Protection of L. rhamnosus by spray drying using two prebiotics colloids to enhance the viability. Carbohydr. Polym. 2014, 102, 423-430. [CrossRef]

70. Saénz, C.; Tapia, S.; Chávez, J.; Robert, P. Microencapsulation by spray drying of bioactive compounds from cactus pear (Opuntia ficus-indica). Food Chem. 2009, 114, 616-622. [CrossRef]

(C) 2020 by the authors. Licensee MDPI, Basel, Switzerland. This article is an open access article distributed under the terms and conditions of the Creative Commons Attribution (CC BY) license (http://creativecommons.org/licenses/by/4.0/). 